\title{
Late Jurassic aptychi from the La Caja Formation of northeastern Mexico
}

\author{
Patrick Zell, Wolfgang Stinnesbeck, Seija Beckmann
}

\section{Patrick Zell}

Patrick.Zell@geow.uni-heidelberg.de

Hessisches Landesmuseum Darmstadt,

Friedensplatz 1, 64283 Darmstadt, Germany.

\section{Wolfgang Stinnesbeck}

Institut für Geowissenschaften, Universität Heidelberg, Im Neuenheimer Feld 234, 69120 Heidelberg, Germany.

\section{Seija Beckmann}

Institut für Geowissenschaften, Universität Heidelberg, Im Neuenheimer Feld 234, 69120 Heidelberg, Germany
BOL. SOC. GEOL. MEX. 2016

VOL. 68 NO. 3

P. $515-536$

\section{ABSTRACT}

Five taxa of Kimmeridgian to Tithonian (Upper Jurassic) aptychi are here described from the La Caja Formation of northeastern Mexico. Laevaptychus (Latuslaevaptychus) latus meyrati Trauth, 1931, L. (Hoplisuslaevaptychus) mexicanus (Castillo and Aguilera, 1895), L. (Autharislaevaptychus) favrei Trauth, 1931, Lamellaptychus lamellosus (Parkinson, 1811) and Lam. murocostatus Trauth, 1929 were previously known from the Tethyan Realm. In northeastern Mexico, records of Lamellaptychus are restricted to the upper lower Kimmeridgianlower upper Tithonian, while Laevaptychus is presently restricted to the uppermost Kimmeridgianuppermost Tithonian.

\section{Keywords: Ammonites,} aptychi, Late Jurassic, northeastern Mexico.

\section{RESUMEN}

Se describen cinco taxones de aptychus del Kimmeridgiano y Tithoniano (Jurásico tardío) procedentes de la Formación La Caja del noreste de México. Laevaptychus (Latuslaevaptychus) latusmeyrati Trauth, 1931, L. (Hoplisuslaevaptychus) mexicanus (Castillo y Aguilera, 1895), L. (Autharislaevaptychus) favrei Trauth, 1931, Lamellaptychus lamellosus (Parkinson, 1811) y Lam. murocostatus Trauth, 1929 habian sido reportados previamente en el dominio tetisiano. En el noreste de México, Lamellaptychus está restringido al lapso entre la parte alta del Kimmeridgiano inferior y la parte inferior del Tithoniano tardio, mientras que Laevaptychus está actualmente restringido del Kimmeridgiano superior al Tithoniano superior.

Palabras clave: Amonites aptychus, Jurásico tardío, noreste de México. 


\section{Introduction}

The Late Jurassic opening of the Gulf of Mexico was accompanied by widespread rifting and continental extension related to sea-floor spreading in the Gulf of Mexico, but the area remained at least temporarily isolated from both the European Realm and the Pacific, with the Florida uplift to the east and the Sinaloa Magmatic Arc to the west forming barriers (e.g, Imlay, 1941; Goldhammer, 1999; Goldhammer and Johnson, 2001; Stinnesbeck and Frey, 2014). The irregular sea bottom topography and heterogeneity of eco-sedimentary conditions in the ancient northwestern margin of the Gulf of Mexico were used to explain differential ammonite records and endemism as well as the low presence of Tethyan taxa (e.g., Olóriz, 1992; Villaseñor et al., 2012).

Jurassic aptychi were hitherto only sporadically mentioned from northeastern Mexico (Burckhardt, 1930; Verma and Westermann, 1973). From other areas of the country aptychi were illustrated by Laur (1871), Erben (1956), or López-Caballero (2009), but only a few formal descriptions exist to date (Castillo and Aguilera, 1895; Villaseñor and González-Arreola, 1988; Zell et al., 2014), even though marine sedimentary rocks of Jurassic age are widespread in northeastern and eastern Mexico and known to be rich in diverse ammonite assemblages. In consequence, the data base regarding the palaeobiogeographic distribution and stratigraphic occurrence of aptychi is exceedingly limited in Mexico.

Here we present a collection of 18 well-preserved aptychi from the Kimmeridgian (Upper Jurassic)-lowermost Berriasian (lowermost Cretaceous) La Caja Formation of southern Coahuila, southern Nuevo León and northern San Luis Potosî states (Fig. 1). The specimens were collected from different stratigraphic levels within the La Caja Formation and were assigned to Laevaptychus ( $\mathrm{La}$ tuslaevaptychus) latus meyrati Trauth, 1931, L. (Hoplisuslaevaptychus) mexicanus (Castillo and Aguilera, 1895), L. (Autharislaevaptychus) favrei Trauth, 1931,
Lamellaptychus lamellosus (Parkinson, 1811) and Lam. murocostatus Trauth, 1929.

\subsection{STRATIGRAPHIC AND GEOLOGIC OVERVIEW}

The La Caja Formation and its equivalents show an overall transgressive lithostratigraphic sequence (Jenchen, 2007). Lithologies of the La Caja Formation are siliciclastic (predominantly siltstone, shale and marl) and were deposited under hemipelagic conditions (e.g., Michalzik, 1988; Zell et al., 2013).

Fossils are locally abundant and occasionally preserved three-dimensionally in calcareous concretions. Diverse ammonite assemblages have been described (e.g., Burckhardt, 1906, 1930; Imlay, 1938, 1939; Cantú-Chapa, 1963, 2006; Verma and Westermann, 1973; Olóriz et al., 1998, 1999; Villaseñor et al., 2000; Zell and Stinnesbeck, 2015), but belemnites (e.g., López-Caballero, 2009; Zell et al., 2013), bivalves (e.g., Mora et al., 2000; Zell et al., 2014, 2015) and brachiopods (Castillo and Aguilera, 1895) were also recorded as well as radiolarians and calpionellids (e.g., Adatte et al., 1994, 1996). Marine vertebrate remains include fishes, ichthyosaurs, crocodiles and pliosaurs (e.g., Frey et al., 2002; Buchy et al., 2003, 2005; Zell et al., 2014). Based on the faunal contents (e.g., ammonites, calpionellids), a lower Kimmeridgian to lowermost Berriasian was assigned to the La Caja/La Casita formations (e.g., Adatte et al., 1994, 1996; Villaseñor et al., 2000, 2012; Olóriz et al., 2003; Zell et al., 2013).

Aptychi are rare in the La Caja Formation, as compared to the abundance and diversity of ammonites. Specimens described here were collected during the 1990`s by one of us (Wolfgang Stinnesbeck). For the location of sites, see Figure 1; for stratigraphic position within the La Caja Formation, see Figure 2. Biostratigraphic assignation of strata investigated here is based on ammonite occurrences, of which representative specimens from the El Verde site (San Luis Potosí) are illustrated in Figure 3. 

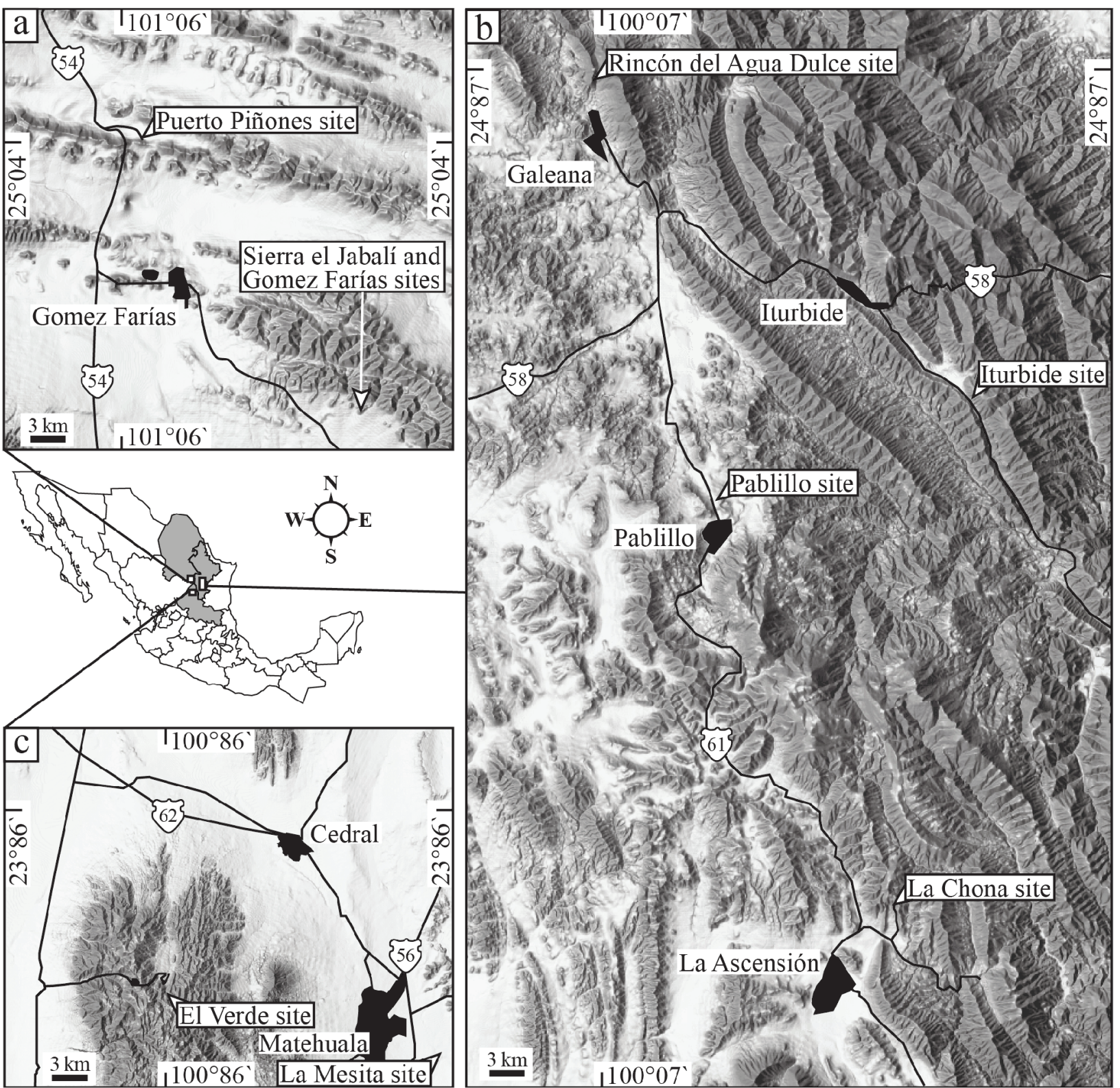

Figure 1 Map of Mexico with insets of northeastern Mexico showing sites, from which aptychi described here were collected. a: localities in southeastern Coahuila State (Puerto Piñones: N252'39.813"/W101 $3^{\prime} 19.209$ ”; Sierra el Jabalí and Gomez Farías: N24 $\left.55^{\prime} 26.591 " / W_{100}^{\circ} 56^{\prime} 58.533^{\prime \prime}\right)$; b: localities in southern Nuevo León State; c: localities in northern San Luis Potosí State (El Verde: N2340’37.343"/W10051'15.553"). Map modified after INEGI (2015).

\section{Systematic paleontology}

The nomenclatural elements of aptychi are illustrated in Figure 4. Their morphological descrip- tion follows Trauth (1927), Gąsiorowski (1959), Farinacci et al. (1976), Turculet and Grigore (2006), Měchová et al. (2010, and sources mentioned therein) and Vašíček et al. (2012). For type species concerning mentioned subgenera of the genus Laevaptychus see Turculet, (2000). All specimens described here are housed in the Colección de Paleontología de Coahuila at the Museo del 


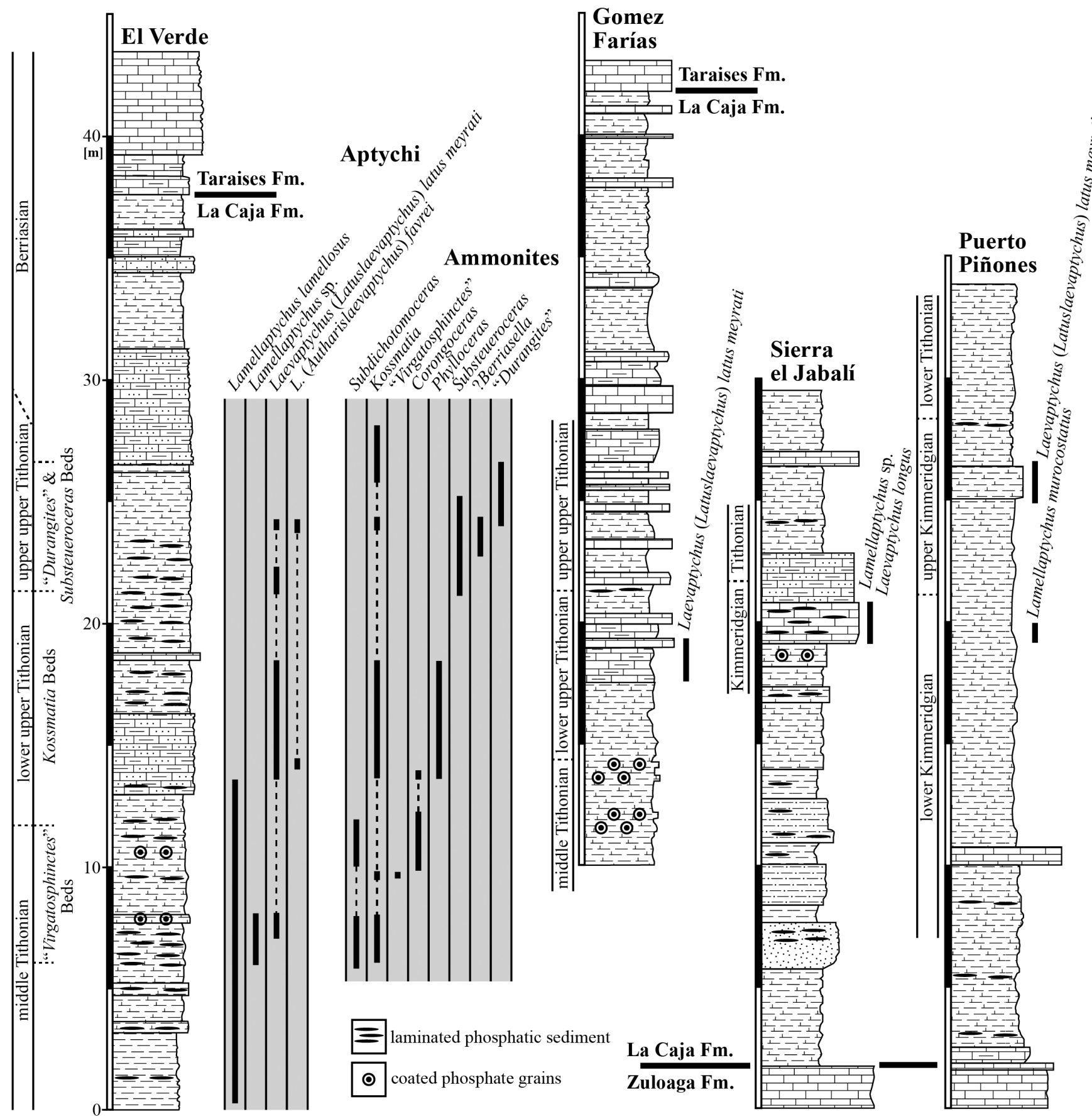
limestone sandy limestone

Figure 2 Lithostratigraphic columns of the La Caja Formation in northeastern Mexico with occurrences of aptychi. For locations of sections see Figure 1. The most abundant and diverse record of aptychi is from El Verde, where the range of co-occurring ammonite genera is also illustrated and indicates a middle to uppermost Tithonian range of deposition. Elsewhere in the area, aptychi are rare. Specimens are here documented from the lower upper Tithonian Kossmatia Beds at Gomez Farías (Velasco Segura, 2005), and from the uppermost Kimmeridgian Beckeri Zone at Sierra el Jabalí (Zell et al., 2014) and Puerto Piñones (López-Caballero, 2009; Zell and Stinnesbeck, 2015). Ammonite bio-chronostratigraphy after Villaseñor et al. (2012) and references therein. 


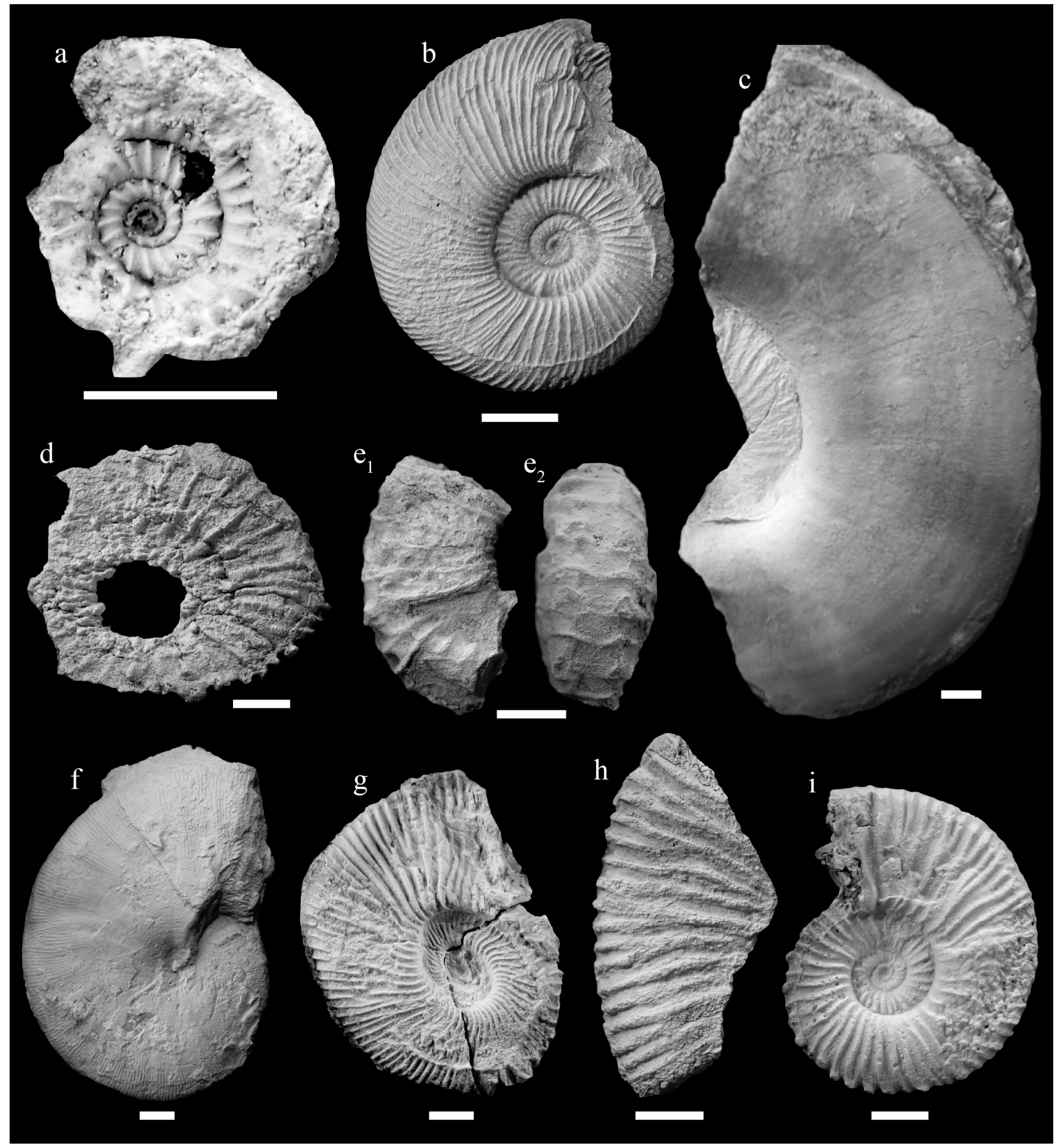

Figure 3 Representative ammonites from the La Caja Formation at El Verde. a: Subdichotomoceras sp. (CPC-1266); b: Kossmatia sp. (CPC-1267); c: large whorl fragment of "Virgatosphinctes" cf. communis (Spath, 1931) (CPC-1268); d: Corongoceras sp. (CPC-1269); e: whorl fragment of Corongoceras sp., lateral (e1) and ventral (e2) views (CPC-1270); f: Phylloceras subplicatus Burckhardt, 1912 (CPC1271); g: Substeueroceras sp. (CPC-1272); h: whorl fragment of ?Berriasella sp. (CPC-1273); i: "Durangites" sp. (CPC-1274). Scale bars $=10 \mathrm{~mm}$. 


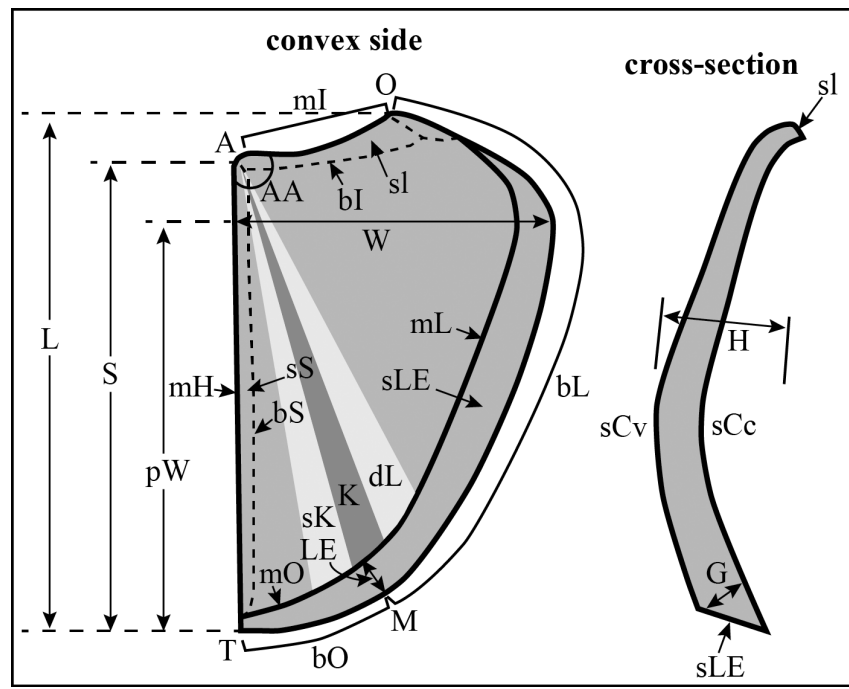

Figure 4 Morphological nomenclature of aptychi illustrated on a hypothetical convex side (outer surface) and cross-section. A, apex; $\mathrm{O}$, umbilical point; $\mathrm{T}$, terminal point; $\mathrm{M}$, marginal point; $b S$, symphysal edge; bl, inner edge; bO, outer edge; bL, lateral edge; $\mathrm{mH}$, harmonic margin (symphysis); $\mathrm{ml}$, inner margin; $\mathrm{mL}$, lateral margin; $\mathrm{mO}$, outer margin; sS, symphysal surface (symphysal facet); sl, internal surface (inner facet); sLE, lateral-external surface (lateral-outer facet); dL, lateral depression; K, keel; sK, keel slope. Parameters: L, maximum length of valve; $S$, distance between apex and terminal point; $W$, maximum width of valve; pW, width projection; LE, width of lateral-external surface in a median region of valve; $G$, thickness of valve at the position of LE; H, maximum height of valve; $A A$, apical angle; $\mathrm{SCv}$, convex surface of valve; sCc, concave surface of valve. Redrawn after Trauth (1931), Gąsiorowski (1960) and Turculeț and Grigore (2006).

Desierto, Saltillo, Coahuila, Mexico. Abbreviation of this collection is CPG.

Class Cephalopoda Cuvier, 1787

Order Ammonoidea Zittel, 1884

Family uncertain (sensu Vašíček et al., 2012)

Genus Laevaptychus Trauth, 1927

Type species: Aptychus meneghinï de Zigno, 1870

Subgenus Latuslaevaptychus Gąsiorowski, 1960

Laevaptychus (Latuslaevaptychus) latus meyrati Trauth, 1931

(Figure 5)
1857. Trigonellites acutus Ooster, p. 25, pl. 6, fig. 16. 1864. Aptychus flamandi Thurmann and Etallon,

1872 - Loriol et al., p. 69.

1876. Aptychus meyrati Favre, p. 61, pl. 6, fig. 7. 1925. Aptychus cf. meyrati Favre, 1876 - Spath, p. 33.

1931. Laevaptychus latus (Parkinson, 1811) var. nov. meyrati - Trauth, p. 75, pl. 1, fig. 4.

1948. Laevaptychus latus (Parkinson, 1811) var. meyrati - Trauth, p. 171.

1960. Laevaptychus latus (Parkinson, 1811) var.

meyrati Trauth, 1931 - Răileanu and

Năstăseanu, p. 24, pl. 9, fig. 30.

2006. Laevaptychus (Latuslaevaptychus) latus meyrati

Trauth, 1931 - Turculeț and Grigore, p. 30, pl.

1, figs. 1, 2.

Material. One complete left valve (CPC-1179), one complete right valve (CPC-1177), one paired valve (CPC-1452), one fragmented left valve (CPC-1180) and two fragmented right valves (CPC-1181, CPG-1178) from El Verde, State of San Luis Potosí; one complete left valve (CPC1427) from Gomez Farías and one fragmented right valve (CPC-1428) from Puerto Piñones, State of Coahuila. Dimensions are provided in Table 1 and abbreviations used therein are explained in Figure 4.

Description. Medium to large $(\mathrm{L}=21.1 \mathrm{~mm}$ to $62.5 \mathrm{~mm} ; \mathrm{W}=16.7 \mathrm{~mm}$ to $41.6 \mathrm{~mm}$ ), medium convex, thick-walled valves $(\mathrm{G}=3.1 \mathrm{~mm}$ to 5.4 $\mathrm{mm}$ ) with an elongated, subtriangular outline. The inner edge is straight in small-sized specimens (Fig. $5 \mathrm{a}-\mathrm{c}, \mathrm{f}, \mathrm{h}$ ) and slightly concave in large individuals (Fig. 5d, e, g). The inner margin is straight to slightly convex. The lateral margin is convex, widely rounded; the outer margin is short and convex. The harmonic margin and the symphysal edge are almost straight, slightly convex. The lateral external surface is convex. The convexity of the valve is strongest at the apical region just above the position of maximum width. The convexity gradually decreases towards the lateral and outer margins. The convex side is sub-irregularly covered with 

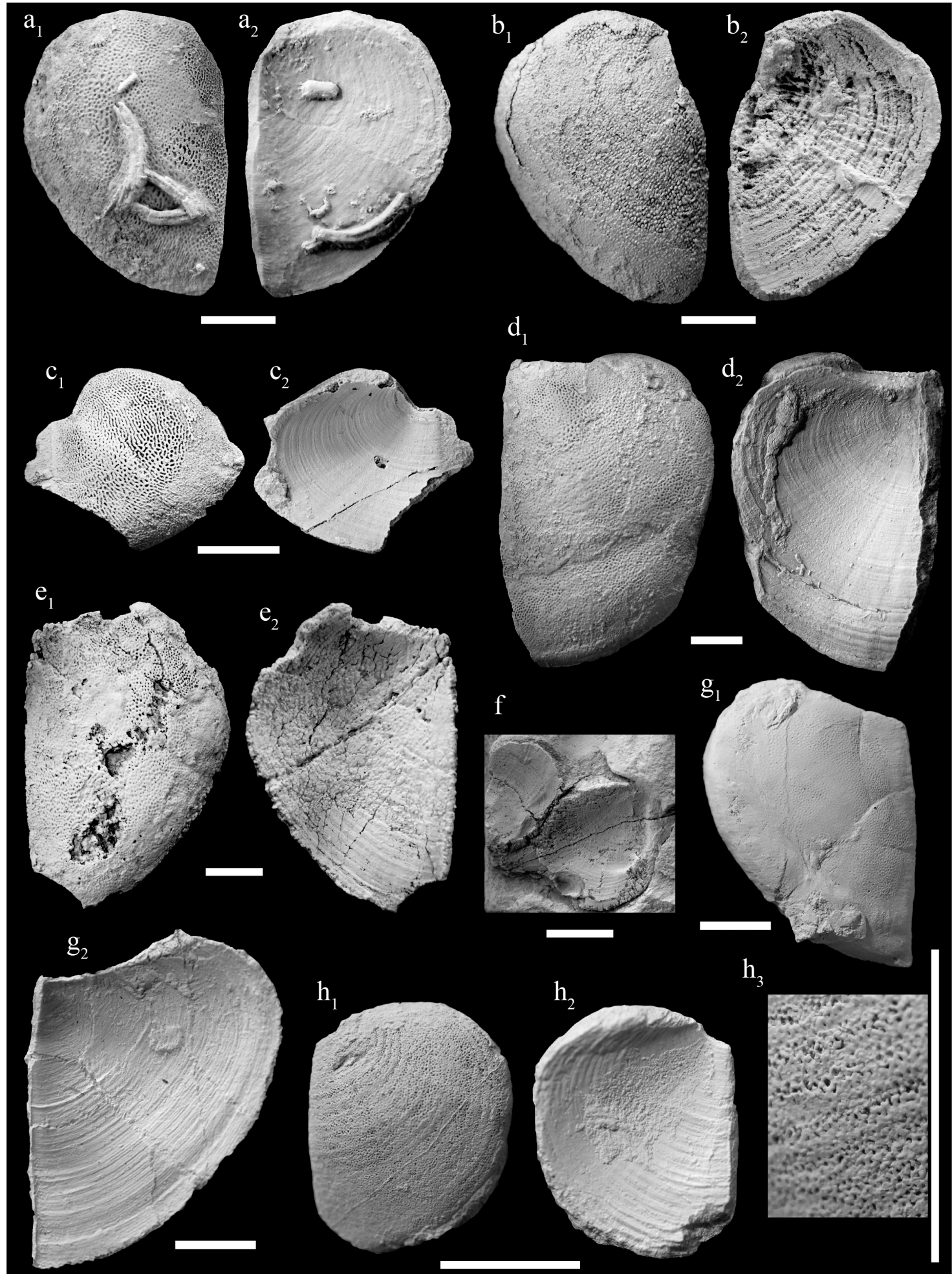

h
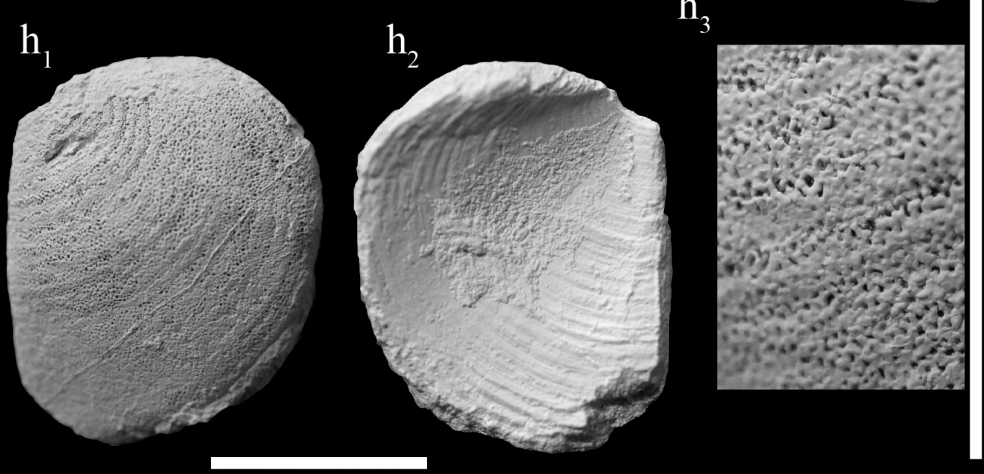

Figure 5 Laevaptychus (Latuslaevaptychus) latus meyrati Trauth, 1931 from the La Caja Formation at El Verde (a-f), Gomez Farías (g) and Puerto Piñones (h). a: left valve, convex $\left(a_{1}\right)$ and concave $\left(a_{2}\right)$ side views (CPC-1179); b: left valve, convex $\left(b_{1}\right)$ and concave $\left(b_{2}\right)$ side views (CPC-1180); c: fragmented right valve, convex $\left(c_{1}\right)$ and concave $\left(c_{2}\right)$ side views (CPC-1181); d: right valve, convex $\left(d_{1}\right)$ and concave $\left(d_{2}\right)$ side views (CPC- 1177); e: right valve, convex $\left(e_{1}\right)$ and concave $\left(e_{2}\right)$ side views (CPC-1178); f: fragments of paired valves, concave side views (CPC-1425); g: left valve, convex $\left(g_{1}\right)$ and concave $\left(g_{2}\right)$ side views (CPC-1427); $h$ : right valve, convex $\left(h_{1}\right.$, $\left.h_{3}\right)$ and concave side $\left(h_{2}\right)$ views (CPC-1428). Scale bars $=10 \mathrm{~mm}$. 
Table 1. Morphometry $(\mathrm{mm})$ of specimens described here.

\begin{tabular}{|c|c|c|c|c|c|c|c|c|c|c|c|c|c|c|}
\hline CPC- & $\mathbf{L}$ & $\mathbf{S}$ & W & $\mathbf{p W}$ & LE & G & $\mathbf{H}$ & S/L & pW/L & G/W & $\mathbf{L E} / \mathbf{L}$ & $\mathbf{H} / \mathbf{W}$ & W/L & $\mathbf{A A}$ \\
\hline 1179 & 35.1 & 30 & 24.9 & 23.2 & 4.4 & 4.1 & 5.1 & 0.84 & 0.66 & 0.16 & 0.13 & 0.2 & 0.71 & $114^{\circ}$ \\
\hline 1180 & 38.4 & - & 27.6 & - & 5.2 & 4.5 & 6.3 & - & - & 0.16 & 0.14 & 0.23 & 0.72 & $112^{\circ}$ \\
\hline 1181 & - & - & 21.7 & - & - & - & 6.1 & - & - & - & - & 0.28 & - & - \\
\hline 1177 & 62.5 & 56.9 & 41.6 & 40.4 & 6.6 & 5.4 & 8.7 & 0.91 & 0.65 & 0.13 & 0.11 & 0.21 & 0.67 & $94^{\circ}$ \\
\hline 1178 & - & - & 34.1 & - & 5.6 & 4.8 & 9.6 & - & - & 0.14 & - & 0.28 & - & - \\
\hline 1425 & 21.1 & 16.1 & 16.7 & 11 & - & - & - & 0.76 & 0.52 & - & - & - & 0.79 & $92^{\circ}$ \\
\hline 1427 & 38.9 & 34.5 & 29.5 & 30.4 & 4.9 & 4.9 & 6 & 0.89 & 0.78 & 0.17 & 0.13 & 0.2 & 0.76 & $96^{\circ}$ \\
\hline 1428 & 24.2 & - & 19.3 & - & - & 3.1 & 5.2 & - & - & 0.16 & - & 0.27 & 0.8 & - \\
\hline
\end{tabular}

circular, suboval and subpolygonal pores $\left(\right.$ Fig. $\left.5 \mathrm{~h}_{3}\right)$. The valve is internally sponge-like; pores are smaller, more regular sized and more abundant at the lateral external surface. The convex side is covered with concentric rings of unequal widths and distribution, following the outline of the inner, lateral and outer margins. Radial wrinkles are present in three specimens (Fig. $5 b_{1}, d_{1}, h_{1}$ ); they originate at the apex and extend to the lateral and outer margins; they are less prominent and less abundant compared to the concentric rings. Pores remain unaffected at the concentric rings and at the position of radial rings and wrinkles. The concave side is covered with fine, concentric growth lines of unequal width and strength, following the outline of the inner, lateral and outer margins. Radial lines (major depressions, minor swellings) originate from the apex and reach the lateral and outer margins without interruption. They gradually increase in width towards the lateral and outer margins; growth lines remain unaffected in size and width at the radial lines. The largest specimen CPC1177 exhibits 10 radial lines (Fig. $5 \mathrm{~d}_{2}$, six depressions, 4 swellings). One specimen (CPC-1425, Fig. 5f) presents paired valves.

Discussion. The values of the morphometric indexes (Table 1) of our specimens of Laevaptychus (Latuslaevaptychus) latus meyrati Trauth, 1931 stay within the limits of the subgenus Latuslaevaptychus (Gąsiorowski, 1960, table 6) and of the species
L. latus (Parkinson, 1811). According to Trauth (1931, p. 71), L. latus is defined by the following indexes: $\mathrm{W} / \mathrm{L}=0.67$ to $0.8, \mathrm{pW} / \mathrm{L} \geq 0.62, \mathrm{H} / \mathrm{W}$ $<0.4$ and $\mathrm{S} / \mathrm{L}>0.77$. Our specimens are medium-sized compared to L. latus, which, according to Trauth (1931), reaches an average width (W) of $48 \mathrm{~mm}$ and length $(\mathrm{L})$ of $63 \mathrm{~mm}$. Only our largest specimen (CPC-1177, Fig. 5d) reaches a similar size. Smaller-sized specimens were also described by Spath (1925).

According to Trauth (1931), the subspecies Laevaptychus (Latuslaevaptychus) latus meyrati is similar in size and dimensions to L. latus with average (av.) $\mathrm{W} / \mathrm{L}=0.67$ to $0.76, \mathrm{G}_{\text {max. }}=5.5 \mathrm{~mm}$ and an average apical angle of between $90^{\circ}$ and $100^{\circ}$. The average values defined for the subspecies fit well with the morphometric measurements of our specimens: $\mathrm{W} / \mathrm{Lav} .=0.74, \mathrm{G}_{\text {max. }}=5.4 \mathrm{~mm}$ and $\mathrm{AA}_{\text {av }}$ $=101.6^{\circ}$. Our specimens belong to Laevaptychus group C of Trauth (1931, p. 66, stout Laevaptychi, $\mathrm{W} / \mathrm{L}$ between 0.67 and 0.8 ), based on their W/L values. The $\mathrm{G} / \mathrm{W}_{\mathrm{av}}$ value of 0.153 in our material fits measurements of Turculet and Grigore (2006, $\mathrm{G} / \mathrm{W}=0.16, \mathrm{p} .30)$ for the subgenus, which are comparatively lower compared to L. latus (Parkinson, 1811; G/W $\approx 0.21$, see Turculet, and Grigore, 2006, p. 30). According to Trauth (1931, p. 77), the most characteristic feature for the subspecies L. (Latuslaevaptychus) latus meyrati is the presence of concentric and/or radial rings of unequal width and distribution on the convex side, which are also 
visible in our specimens. However, the occurrence of radial lines was interpreted by Měchová et al. (2010) to be related to an exceptionally favourable type of preservation.

Similar concentric rings are also present in L. longus, L. favrei and L. meneghinii var. rugosa (Trauth, 1931). Laevaptychus (Latuslaevaptychus) latus meyrati can be distinguished from L. longus $(\mathrm{W} / \mathrm{L}<0.67)$ and $L$. favrei $(\mathrm{W} / \mathrm{L}<0.5)$ by the larger $\mathrm{W} / \mathrm{L}$ index and from L. meneghinii var. rugosa by its larger valve thickness (cf. Trauth, 1931, p. 86).

Occurrence. In Europe, most representatives of the genus Laevaptychus occur by the end of the early Tithonian (see Schindewolf, 1958; Gąsiorowski, 1960; Turculet, 2000). Laevaptychus latus (Parkinson, 1811) is common throughout the Upper Jurassic and is abundant in the Alpine-Mediterranean region (summarized by Trauth, 1931 and Renz, 1972). It was also recorded in southern Arabia (Beydoun, 1966), Tunisia, Somalia (e.g, Valduga, 1954) and western North Atlantic (Site 105, Leg XI, Deep Sea Drilling Project; Renz, 1972). In Mexico, the first records of Aptychus latus (= Laevaptychus latus sensu Trauth, 1931) are provided by Laur (1871) and Castillo and Aguilera (1895, p. 49) from the Upper Jurassic of the La Caja Formation at Sierra de Catorce, State of San Luis Potosí and by Burckhardt (1930, p. 77) from the upper Kimmeridgian "Couche à Haploceras d. gr. Fialar" of Sierra de Santa Rosa, Mazapil, State of Zacatecas, unfortunately without descriptions and figures.

The subspecies Laevaptychus (Latuslaevaptychus) latus meyrati Trauth, 1931 is a characteristic faunal element from the Tethyan Realm and is known from the Jurassic of the Swiss alps (Ooster, 1857; Fischer-Ooster, 1865), from the Upper Jurassic of Somalia (Spath, 1925) from the Oxfordian of the Swiss alps (Favre, 1876), from the ?Oxfordianupper Tithonian of Romania (Răileanu et al., 1960; Turculet, and Grigore, 2006), from the Kimmeridgian-Tithonian of Germany and Austria (Trauth, 1931), from the middle Kimmeridgian- lower Tithonian of France (Loriol et al., 1872) and from the upper Tithonian of Austria (Trauth, 1948).

In northeastern Mexico, Laevaptychus (Latuslaevaptychus) latus meyrati Trauth, 1931 is present in mixed siliciclastic-limestone lithologies of the La Caja Formation and was identified in the upper Kimmeridgian Beckeri Zone (López-Caballero, 2009; Zell et al., 2014; Zell and Stinnesbeck, 2015) at Puerto Piñones, in the lower upper Tithonian Kossmatia Beds at Gomez Farías and in the middle Tithonian "Virgatosphinctes" Beds, the lower upper Tithonian Kossmatia Beds and the uppermost Tithonian "Durangites" and Substeueroceras Beds at El Verde.

Subgenus Hoplisuslaevaptychus Gąsiorowski, 1960

Laevaptychus (Hoplisuslaevaptychus) mexicanus (Castillo and Aguilera, 1895)

(Figure 6a, b)

1895. Aptychus mexicanus Castillo and Aguilera, p. 45, pl. 22, fig. 8.

1931. Laevaptychus mexicanus (Castillo and Aguilera, 1895) - Trauth, p. 131, fig. G14.

1978. Laevaptychus mexicanus (Castillo and Aguilera, 1895) - Renz, p. 499, pl. 1, figs. 1a, 1 b.

Material. One fragmented, almost complete left valve (CPG-1437) from Rincón del Agua Dulce and one fragmented, large left valve (CPG-1438) from Iturbide, State of Nuevo León. The specimens were collected from marls of the La Caja Formation, a precise origin of layers is not known. Dimensions are provided in Table 2 and abbreviations used therein are explained in Figure 4.

Table 2. Morphometry $(\mathrm{mm})$ of specimens described here.

\begin{tabular}{|c|c|c|c|c|c|c|c|c|c|c|}
\hline CPC- & L & S & W & pW & H & S/L & $\mathbf{p W} / \mathbf{L}$ & $\mathbf{H} / \mathbf{W}$ & $\mathbf{W} / \mathbf{L}$ & $\mathbf{A A}$ \\
\hline 1437 & 30.6 & 30.1 & 24.3 & 17.6 & - & 0.98 & 0.58 & - & 0.79 & $90^{\circ}$ \\
1438 & 66.2 & 57.2 & 55.7 & 45.3 & 56.1 & 0.86 & 0.68 & 1 & 0.88 & - \\
\hline
\end{tabular}




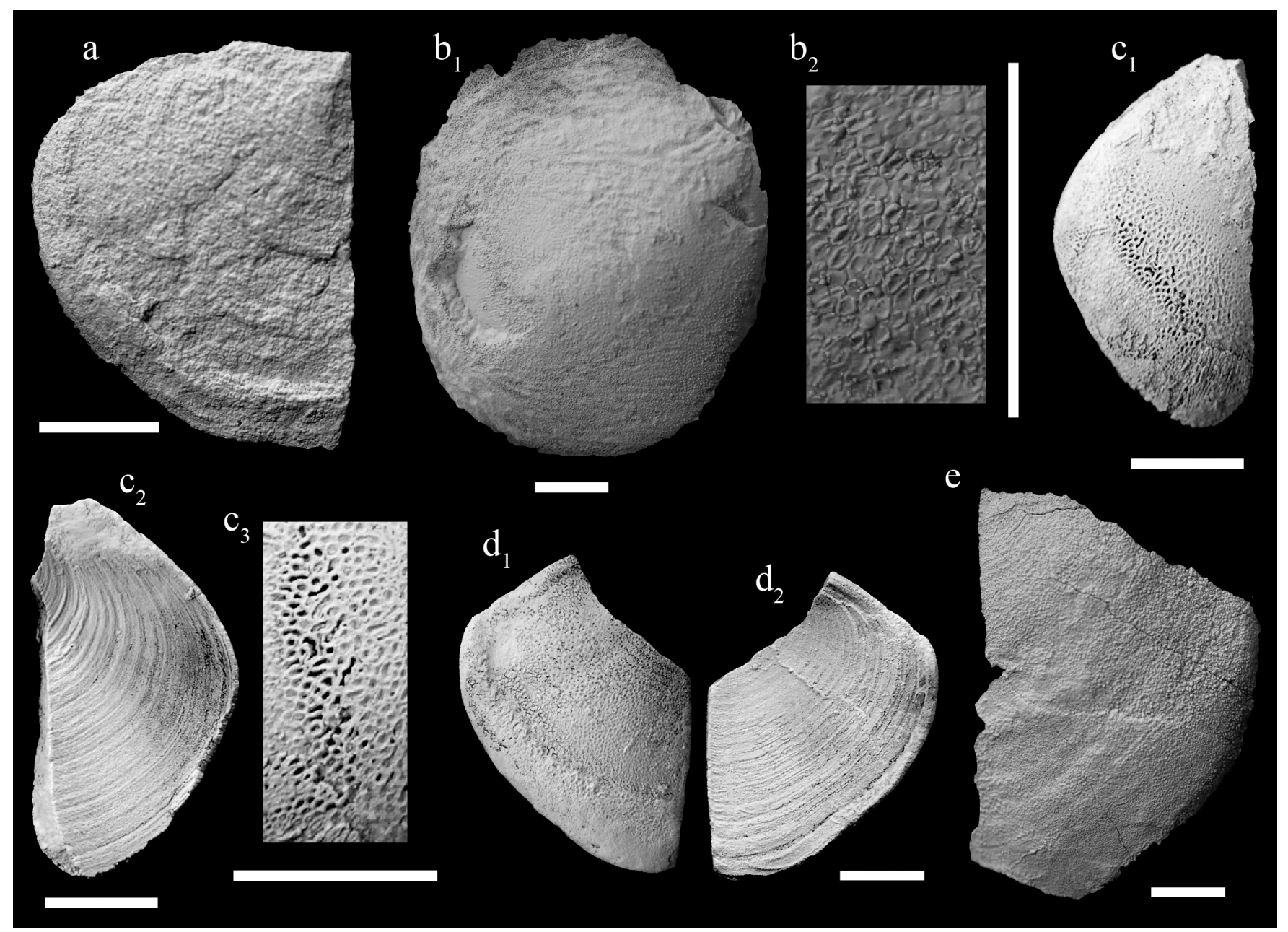

Figure 6 Laevaptychus (Hoplisuslaevaptychus) mexicanus (Castillo and Aguilera, 1895) (a, b) and Laevaptychus

(Autharislaevaptychus) favrei Trauth, 1931 (c-e) from the La Caja Formation of northeastern Mexico. a: left valve from Rincón del Agua Dulce, convex side view (CPC-1437); b: left valve from Iturbide, convex side view (CPC-1438); c: left valve from El Verde, convex $\left(c_{1}, c_{3}\right)$ and concave side $\left(c_{2}\right)$ views (CPC-1439); d: fragmented left valve from El Verde, convex $\left(d_{1}\right)$ and concave $\left(d_{2}\right)$ side views $(C P C-$ 1394); e: right valve from La Chona, convex side view (CPC-1350). Scale bars $=10 \mathrm{~mm}$.

Description. Medium $(\mathrm{L}=20.6 \mathrm{~mm})$ to large $(\mathrm{L}=66.2 \mathrm{~mm})$, medium convex, very compressed $(\mathrm{H} / \mathrm{W}=1)$, subtrigonal valves. The harmonic margin is almost straight, slightly convex. The inner margin is short and concave, the lateral margin is wide and circular and the outer margin is short and convex. The transition between the margins is almost continuous; it can be recognized by the transition from concave (inner margin) to circular convex (lateral margin) and to slightly less convex (outer margin). The maximum shell width is placed about at the center of the valve's length.
The convexity of the valve is strongest at the center of the valve at the position of maximum shell width. The convexity gradually decreases towards the lateral and outer margins. The convex side is covered with widely spaced, oval pores (Fig. $\left.6 b_{2}\right)$ of homogenous size and distribution; rounded pores are minor represented. Shallow concentric rings of unequal width and distribution are present on the convex side of specimen CPC-1437 (Fig. 6a).

Discussion. The $\mathrm{S} / \mathrm{L}$ and $\mathrm{pW} / \mathrm{L}$ values of our specimens (Table 2) fit well to measurements for the subgenera Latuslaevaptychus, Meneghiniilaevap- 
tychus and Hoplisuslaevaptychus defined by Gasiorowski (1960, table 6), of which only the subgenus Hoplisuslaevaptychus presents high $\mathrm{H} / \mathrm{W}$ values $(\geq$ 0.42). Based on the high $\mathrm{H} / \mathrm{W}$ value of 1.01 , our specimens are therefore assigned to this subgenus, and here to Laevaptychus group C of Trauth (1931, p. 66, stout laevaptychi, W/L between 0.67 and 0.8), based on their $\mathrm{W} / \mathrm{L}$ values.

The type material of Aptychus mexicanus Castillo and Aguilera (1895) (= Laevaptychus mexicanus sensu Trauth, 1931) was defined by the following parameters: $\mathrm{AA}=90^{\circ}, \mathrm{S} / \mathrm{L}=0.97, \mathrm{pW} / \mathrm{L}=0.56$ and $\mathrm{W} / \mathrm{L}=0.86$, which are comparable to values measured in our specimens (Table 2). In addition to the parameters, Laevaptychus (Hoplisuslaevaptychus) mexicanus is also defined by an almost straight harmonic margin, a right apical angle, and by a slightly concave inner margin, which merges continuously into a wide, circular lateral margin. The outer margin is short and slightly less convex, meeting the terminal point in an obtuse angle $(\approx$

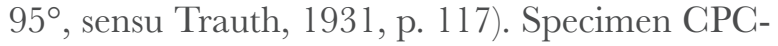
$1438(\mathrm{~L}=66.2 \mathrm{~mm}$; Fig. 6b) is relatively large for the species $(\mathrm{L}=35 \mathrm{~mm}$ in Castillo and Aguilera, 1895); it is here interpreted to represent an aptychus of an adult ammonite.

L. latissimus Trauth, 1931 is similar to $L$. $(H$.) mexicanus but differs in the position of the maximum valve width, which is placed closer to the inner margin (see Trauth, 1931, p.116), with resulting $\mathrm{pW} / \mathrm{L}$ values of $\geq 0.62$. The inner margin of $L$. longus (v. Meyer, 1831) is more concave and the apical angle is larger than that of $L$. $(H$.) mexicanus.

Occurence. The subgenus Hoplisuslaevaptychus is known from the upper Oxfordian-Tithonian of Europe (Gąsiorowski, 1960). Laevaptychus (H.) mexicanus (Castillo and Aguilera, 1895) is known from the ?Oxfordian of the eastern Atlantic (Renz,
1978; Deep Sea Drilling Project site 367) and from the Tithonian of Croatia (Trauth, 1931). The species was first described from the Upper Jurassic (Kimmeridgian or Tithonian) at Sierra de Catorce, San Luis Potosí, central Mexico (Castillo and Aguilera, 1895). In northeastern Mexico, L. (H.) mexicanus is rare.

Subgenus Autharislaevaptychus Gąsiorowski, 1960

Laevaptychus (Autharislaevaptychus) favrei Trauth, 1931

(Figure 6c-e)

1876. Aptychus meyrati Favre, p. 61, pl. 6, fig. 8.

1931. Laevaptychus favrei Trauth, p. 65, pl. 1, fig. 2. 1960. Laevaptychus (Autharislaevaptychus) -

Gąsiorowski, pl. 13, fig. 1.

1962. Laevaptychus (Autharislaevaptychus) favrei-

Gąsiorowski, pl. 3, fig. 3.

Material. Two fragmented left valves (CPC1239, CPC-1394) from El Verde, State of San Luis Potosí and one fragmented right valve (CPC-1350) from La Chona, State of Nuevo León. Dimensions are provided in Table 3 and abbreviations used therein are explained in Figure 4.

Description. Medium sized $(\mathrm{L}=31.1 \mathrm{~mm}$ ), slen$\operatorname{der}(\mathrm{W} / \mathrm{L}=0.58)$, subtrigonal valves of low convexity $(\mathrm{H} / \mathrm{W}=0.16$ and 0.32$)$. The apical angle is acute $\left(62^{\circ}\right)$, the inner margin and the inner edge are short and slightly convex, projecting backwards. They continuously merge into a wide, circular-rounded lateral margin. The outer margin is short, strongly convex; it curves towards the direction of the apex close to the harmonic margin. The thickness of the valve gradually increases from the harmonic margin, respectively symphy-

Table 3. Morphometry $(\mathrm{mm})$ of specimens described here.

\begin{tabular}{|c|c|c|c|c|c|c|c|c|c|c|c|c|c|c|}
\hline $\mathbf{C P C}-$ & $\mathbf{L}$ & $\mathbf{S}$ & $\mathbf{W}$ & $\mathbf{p W}$ & $\mathbf{L E}$ & $\mathbf{G}$ & $\mathbf{H}$ & $\mathbf{S} / \mathbf{L}$ & $\mathbf{p W} / \mathbf{L}$ & $\mathbf{G} / \mathbf{W}$ & $\mathbf{L E} / \mathbf{L}$ & $\mathbf{H} / \mathbf{W}$ & $\mathbf{W} / \mathbf{L}$ & $\mathbf{A A}$ \\
\hline 1439 & 31.1 & 32.3 & 18.3 & 18.4 & 4.2 & 2.9 & 5.9 & 1.03 & 0.59 & 0.16 & 0.14 & 0.32 & 0.58 & $62^{\circ}$ \\
\hline 1394 & - & - & 26.6 & 19.2 & 5.9 & 3 & 4.3 & - & - & 0.11 & - & 0.16 & - & - \\
\hline
\end{tabular}


sal edge, towards the lateral edge and margin. The convex side is irregularly covered with relatively large pores of unequal size (Fig. $6 \mathrm{c}_{3}$ ). The pores are circular, suboval and subpolygonal-elongated (Fig. $6 \mathrm{c}_{1}, \mathrm{c}_{3}$ ). The elongated pores point towards the outer and lateral margins. Concentric lines and wrinkles of unequal size and distribution are present on the convex side. They follow the outline of the outer and lateral margins and appear more abundant at the apical area (Fig. 6d, e). Three radial lines (furrows) are present on the convex side of specimen CPG-1394 (Fig. 6d, $_{1}$. They are best identified in the central area of the valve; they point towards the apex and disappear approximately $14 \mathrm{~mm}$ before the lateral and outer margins. The concave side is covered with sub-regularly-spaced, fine growth-lines (Fig. $6 \mathrm{c}_{2}, \mathrm{~d}_{2}$ ).

Discussion. The G/W and LE/L values of our specimens (Table 3) are within the range of the subgenus Autharislaevaptychus, as defined by Gąsiorowski $(1960$, table 6 ; $\mathrm{G} / \mathrm{W}<0.25$, $\mathrm{LE} / \mathrm{L}<0.2)$. In addition to morphometric values, the presence of relatively large pores on the convex side is also considered to be characteristic by the author (Gąsiorowski, 1960). Our specimens are assigned to the group b of Trauth (1931, p. 40; B/L between 0.5 and 0.67 , slender laevaptychi).

According to Trauth (1931, p. 65), Laevaptychus (Autharislaevaptychus) favrei Trauth, 1931 is characterized by W/L values of about 0.64 , by an acute apical angle and by the backward-projection of the inner edge and margin, which merges into a wide, convex lateral margin without interruption. Similar to L. latus and other related taxa of the genus, concentric lines and radial lines and wrinkles of irregular strength and distribution are also present (Trauth, 1931). However, the occurrence of radial lines is related to an exceptionally favourable type of preservation (Měchová et al., 2010). The outer margin is short, strongly convex; it curves towards the apex close to the harmonic margin. In $L$. $(A$.) favrei, the thickness of the shell is characteristically increasing from the harmonic margin towards the lateral margin, similar to L. longus (v. Meyer, 1831; cf. Trauth, 1931).

Our specimens of Laevaptychus (Autharislaevaptychus) favrei are similar to L. hybonotus (Trauth, 1931, p. 39 ), but the latter is characterized by smaller $\mathrm{W} / \mathrm{L}$ ratios $(<0.5)$.

Occurence. The subgenus Autharislaevaptychus is known from the Callovian-Tithonian of Europe (Gąsiorowski, 1960). Laevaptychus (Autharislaevaptychus) favrei Trauth, 1931 was reported from the Oxfordian of Switzerland (Favre, 1876), Poland (Gąsiorowski, 1960, 1962) and possibly from England and Germany (Trauth, 1931).

In northeastern Mexico, L. (A.) faurei Trauth, 1931 was identified in the lower upper Tithonian Kossmatia Beds and in the uppermost Tithonian "Durangites" and Substeueroceras Beds of the La Caja Formation at El Verde, State of San Luis Potosí, and from the ?Tithonian of La Chona, State of Nuevo León.

Family Lamellaptychidae Měchová et al., 2010 Genus Lamellaptychus Trauth, 1927

Type species: Trigonellites lamellosus Parkinson, 1811

Lamellaptychus lamellosus (Parkinson, 1811) (Figure 7a)

1811. Trigonellites lamellosus Parkinson, p. 184, 186, pl. 13, figs. 10, 11 .

1829. Aptychus imbricatus Meyer, p. 127, 139, 169, pl. 54, fig. 12.

1829. Aptychus imbricatus profundus Meyer, p. 127,

140, 141, 169, pl. 43, fig. 10.

1831. Aptychus imbricatus profundus Meyer, p. 397. 399.

1835. Münsteria sulcata Deslongchamps, p. 66, pl.

11, figs. 10, 11.

1837. Aptychus profundus Voltz, p. 434.

1846-49. Aptychus lamellosus (Parkinson, 1811)-

Quenstedt, p. 312, pl. 22, figs. 20a, b, 23. 
1850-51. Aptychus lamellosus (Parkinson, 1811)-

Bronn, p. 379, pl. 15, fig. 16a-c.

1854. Aptychus profundus Pictet, p. 558.

1854. Aptychus lamellosus (Parkinson, 1811) - Pictet, p. 558 , pl. 47 , fig. $16 \mathrm{a}$, b.

1857. Trigonellites ornatus Ooster, p. 22, pl. 6, fig. 5.

1857. Trigonellites imbricatus Ooster, p. 19, pl. 5, fig. 7.

1857. Trigonellites curvatus Ooster, p. p. 20, pl. 5, fig. 16.

1858. Aptychus lamellosus (Parkinson, 1811) -

Quenstedt, p. 596, 600, 622, pl. 74, figs. 12, 13. 1863. Aptychus euglyptus Oppel, p. 254, 265, pl. 70, fig. 2.

1863. Aptychus lamellosus (Parkinson, 1811) - Oppel, p. 254.

1887-88. Aptychus lamellosus (Parkinson, 1811)-

Quenstedt, p. 917, pl. 99, fig. 20a.

1907. Aptychus aff. crassicauda Toula, p. 82, pl. 12,

fig. 3.

1908. Aptychus lamellosus (Parkinson, 1811) - Engel, p. 402, 414.

1927. Aptychus (Lamellaptychus) lamellosus (Parkinson,

1811) - Trauth, p. 197-199, 223, 234, 237.

1929. Lamellaptychus lamellosus (Parkinson, 1811)-

Trauth, p. 76-77, 79.

1938. Lamellaptychus lamellosus (Parkinson, 1811) -

Trauth, p. 149, pl. 11, figs. 1-5.

1962. Lamellaptychus lamellosus (Parkinson, 1811)-

Gąsiorowski, pl. 3-5.

1965. Lamellaptychus lamellosus (Parkinson, 1811)-

Pozzi, p. 869, pl. 86, fig. 7.

1972. Lamellaptychus lamellosus (Parkinson, 1811)-

Renz, p. 613, p. 2, fig. 4a-c.

2000. Lamellaptychus lamellosus (Parkinson, 1811)-

Turculet, p. 102, pl. 5, figs. 9-15, pl. 6, fig. 5.

Material. One complete right valve (CPG-1182) from El Verde, State of San Luis Potosí. Dimen- sions are provided in Table 4 and abbreviations used therein are explained in Figure 4.

Description. Large-sized $(\mathrm{L}=24.8 \mathrm{~mm}$ ), thin-valved $(\mathrm{G}=2.9 \mathrm{~mm})$, weakly vaulted, elongated-subtrigonal valve. The shell reaches its maximum thickness at the outer margin $(\mathrm{G} / \mathrm{W}=0.15)$. The valve is strongest convex at the apical region, 2 to $4 \mathrm{~mm}$ below the inner edge. The inner edge and margin are straight (Fig. $\left.7 \mathrm{a}_{4}\right)$, the symphysal edge and the harmonic margin are slightly convex. The outer margin is short and convex, the lateral margin arch-shaped. The even symphysal surface and the inner surface are pronounced. The convex side is covered with prominent, simple, slightly arch-shaped ribs. They originate from a shallow ridge situated between the apex and the umbilical point. Broad furrows separate the ribs; they gradual increase in width at the terminal region below the point of inflection. The majority of ribs end at the harmonic margin and some at the outer edge, forming angles of $22^{\circ}$ to $27^{\circ}$. Ribs are steep, acute, wall-like, leaning against the apex and harmonic margin. Ribs follow the outline of the lateral margin, with the exception of S-shaped ribs (sensu Měchová et al., 2010) near the symphysal area; these bend towards the harmonic margin along an axis which meets the harmonic margin near the apex at an angle of about $20^{\circ}$. The last four adult ribs end at the outer margin. Ribs are most prominent in the terminal and lateral regions. They become gradually less prominent towards the apical area, where they almost disappear. At the keel slope, ribs are negligibly inflected at the apical region and become gradually more inflected towards the outer margin.

Discussion. Our specimens exhibit the ribbing pattern regarded as typical for the genus Lamellap-

Table 4. Morphometry $(\mathrm{mm})$ of specimens described here.

\begin{tabular}{|c|c|c|c|c|c|c|c|c|c|c|c|c|}
\hline $\mathbf{C P C}-$ & $\mathbf{L}$ & $\mathbf{S}$ & $\mathbf{W}$ & $\mathbf{p W}$ & $\mathbf{G}$ & $\mathbf{H}$ & $\mathbf{S} / \mathbf{L}$ & $\mathbf{p W} / \mathbf{L}$ & $\mathbf{G} / \mathbf{W}$ & $\mathbf{H} / \mathbf{W}$ & $\mathbf{W} / \mathbf{L}$ & $\mathbf{A A}$ \\
\hline 1182 & 42.8 & 36.4 & 18.8 & 31.4 & 2.9 & 4.3 & 0.85 & 0.73 & 0.15 & 0.23 & 0.44 & $123^{\circ}$ \\
\hline
\end{tabular}




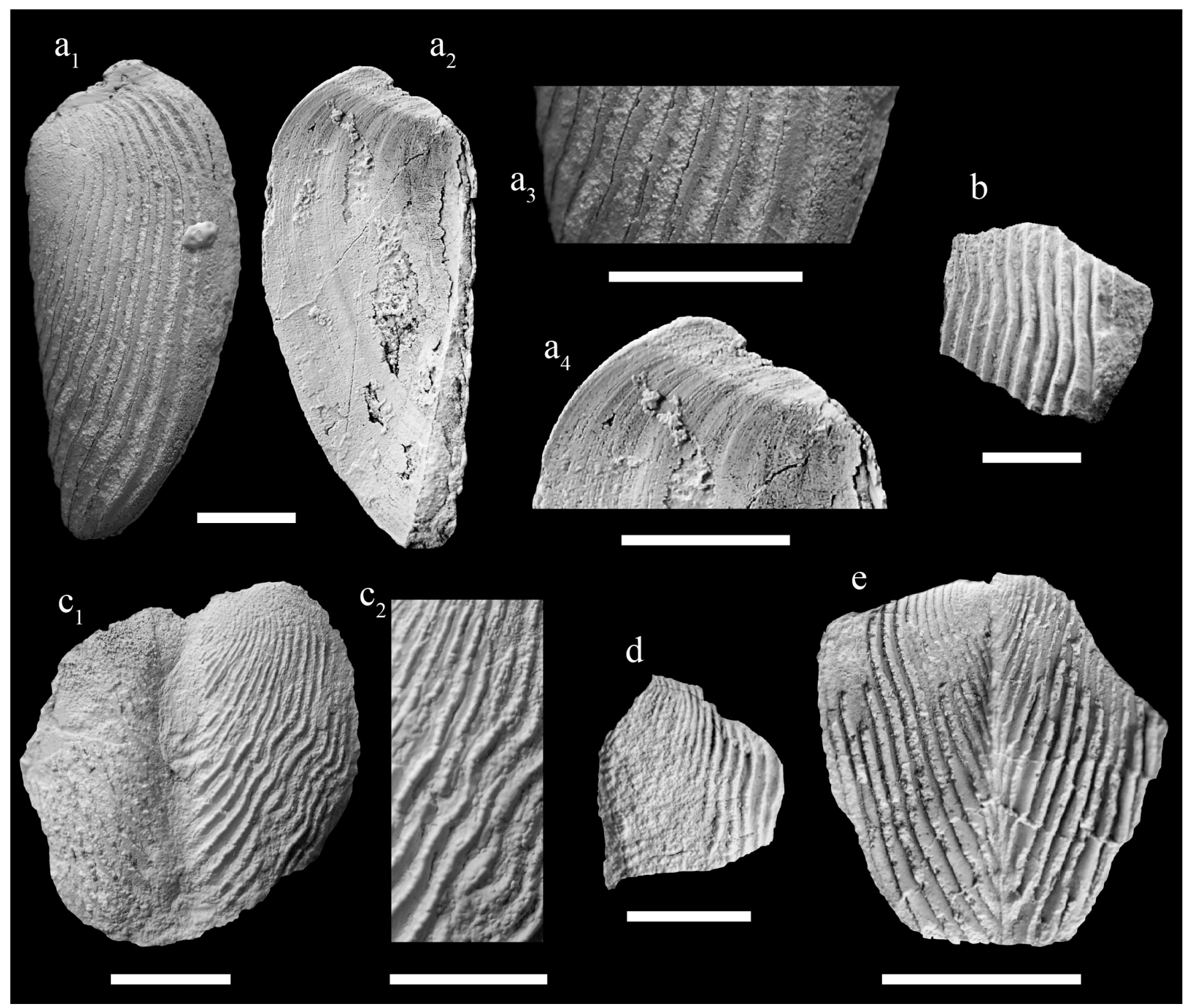

Figure 7 Lamellaptychi from the La Caja Formation of northeastern Mexico. a: Lamellaptychus lamellosus (Parkinson, 1811) from El Verde, right valve, convex $\left(a_{1}, a_{3}\right)$ and concave $\left(a_{2}, a_{4}\right)$ side views (CPC-1182); b: fragment of Lamellaptychus sp. from El Verde, right valve, convex side view (CPC-1183); c: fragmented Lamellaptychus murocostatus Trauth, 1929, paired valves from La Mesita, convex side views (CPC-1351); d: fragment of Lamellaptychus murocostatus Trauth, 1929 from Pablillo, right valve, convex side view (CPC1275); e: fragmented paired valves of Lamellaptychus murocostatus Trauth, 1929 from Rincón del Agua Dulce, convex side view (CPC-1276). Scale bars $=10 \mathrm{~mm}$.

tychus Trauth, 1927 (cf. Měchová et al., 2010, fig. 7D). They belong to lamellaptychid group b of Trauth (1938, p. 159; lamellaptychi without lateral depression).

According to Trauth (1938, p. 150), Lamellaptychus lamellosus (Parkinson, 1811) is characterized by an obtuse apical angle, relatively high $\mathrm{S} / \mathrm{L}$ values, a straight to concave inner margin, an arch-shaped lateral margin, $\mathrm{W} / \mathrm{L}$ values between 0.4 and 0.67 , $\mathrm{pW} / \mathrm{L}$ values $>0.62$, a subtriangular to subparallel-elipsoidal outline, an even symphysal surface, G/W values between 0.12 to 0.25 , by ribs which originate from a shallow ridge situated between the apex and the umbilical point (cf. Meyer, 1829, 
p. 139), by ribs which are S-shaped and inflated, and by the absence of a keel, keel slope and lateral depression.

Lamellaptychus gillieroni Trauth (1938) and L. sparsilamellosus (Gümbel, 1861) are similar to L. lamellosus but the latter is distinguished by the absence of an adsymphysal ridge (cf. Trauth, 1938, p. 151). Lamellaptychus rectecostatus (Peters, 1854) and L. beyrichi (Oppel, 1865) are similar to the valve shape of L. lamellosus, but the latter differs by the presence of inflated ribs and an increase of accompanying furrow width at the terminal region, leading to an arched-shaped contour and a curved approximation to the margin (Trauth, 1938, p. 151).

Occurrence. Lamellaptychus is well known from the Bajocian-Valanginian of the Tethyan Realm (e.g., Carpathians, Gąsiorowski, 1962; France, Fischer, 2003; Spain, Calzada, 1985; distribution summarized by Měchová et al., 2010). Two records of the genus (Lamellaptychus didayi and $L$. angulicostatus) from the Middle Jurassic to ?Lower Cretaceous Puebla Group of southeast to central Mexico are provided by Erben (1956), but without a detailed description. The genus was also identified from the uppermost Kimmeridgian Beckeri Zone at Gomez Farías, State of Coahuila (Lamellaptychus sp.; Zell et al., 2014), from the Kimmeridgian upper Idoceras Beds of Puerto Piñones (Lamellaptychus sp.; López-Caballero, 2009), and from the upper Kimmeridgian Procraspedites-Taramelliceras interval (see Villaseñor et al., 2012) of Sierra de Palotes, State of Durango (Lamellaptychus murocostatus Trauth, 1929; Villaseñor and González-Arreola, 1988).

Lamellaptychus lamellosus (Parkinson, 1811) is abundant in the upper Oxfordian-Tithonian of the Tethyan Realm as summarized by Trauth (1938), and associated ammonites were there identified as Oppelia. The taxon was also reported from the Oxfordian or Kimmeridgian of the western North Atlantic (Site 105, Leg XI, Deep Sea Drilling Project; Renz, 1972).

In northeastern Mexico, L. lamellosus is present in the middle Tithonian "Virgatosphinctes" Beds and in the lower upper Tithonian lower Kossmatia Beds of the La Caja Formation at El Verde, State of San Luis Potosí. The species is relatively abundant at El Verde (field observation), but only one well-preserved specimen was suitable for excavation.

Lamellaptychus murocostatus Trauth, 1929

(Figure 7c-e)

1929. Lamellaptychus murocosta Trauth, p. 77.

1938. Lamellaptychus murocosta Trauth, p. 142, pl.

19, figs. 21-22.

1978. Lamellaptychus murocostatus Trauth, 1938 -

Renz, p. 502, pl. 1, fig. 10.

1988. Lamellaptychus murocostatus Trauth, 1938 -

Villaseñor and González-Arreola, p. 76, fig. 10. 2009. Lamellaptychus sp. - López-Caballero, pl. 10, fig. D4.

Material. Two fragmented, paired valves from $\mathrm{La}$ Mesita (CPC-1351), state of San Luis Potosí and from Rincón del Agua Dulce (CPC-1276), State of Nuevo León, and one fragment (CPC-1275) from Pablillo, State of Nuevo León. The specimens were collected from marls of the La Caja Formation, a precise origin of layers is not known. Dimensions are provided in Table 5 and abbreviations used therein are explained in Figure 4.

Description. Medium-sized ( $\mathrm{L} \approx 32.7 \mathrm{~mm}$ ), thin -shelled valve with a weak lateral depression, keel and a keel slope. The outer margin is not preserved, but the distribution of ribs indicates that a short, convex outer margin existed. The lateral margin is wide and convex, the harmonic margin $(\mathrm{S}=30.7 \mathrm{~mm})$ is straight. A reconstruction of the outline, based on the distribution of ribs, indicates an equal position of the maximum width $(\mathrm{pW}$ $\approx 30 \mathrm{~mm}$ ) and the apex $(\mathrm{S} \approx 10.7 \mathrm{~mm})$, with an $\mathrm{S} / \mathrm{L}$ value of approximately 0.94 . Ribs are promi-

Table 5. Morphometry $(\mathrm{mm})$ of specimens described here.

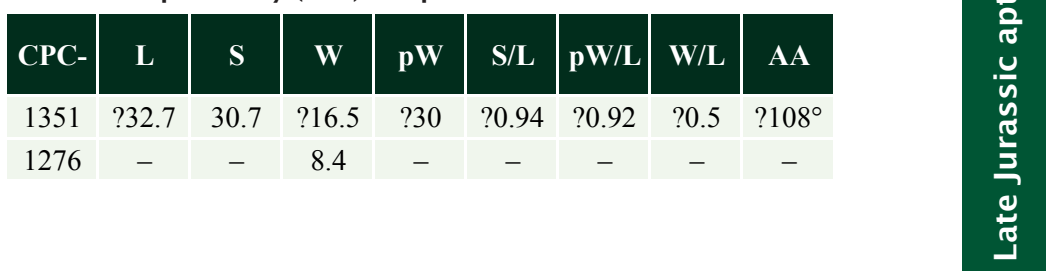


nent, wall-like upward-projected, leaning towards the lateral margin $\left(\right.$ Fig. $\left.7 \mathrm{c}_{2}\right)$. The cross-section of the ribs is rounded to sub-acute. Ribs are slightly higher than wide. Specimen CPC-1351 represents an S-shaped band of ribs between the apical region and at about midway to the lateral margin. A double S-shaped bend of ribs is seen during later ontogenetic stages leaning towards the lateral margin $\left(\right.$ Fig. $7 \mathrm{c}_{2}$ ). The smaller-sized specimen CPC1276 (Fig. 7e) only presents one S-shaped bend of ribs. Broad furrows separate the ribs, but they are less wide when compared to the width of associated ribs. The majority of ribs end at the harmonic margin, but those at the outer edge generate an angle of $24^{\circ}$ to $35^{\circ}$ with the latter. Between the keel and the keel slope, ribs are inflected and curve towards the harmonic margin.

Discussion. Our specimens exhibit the typical ribbing for the genus Lamellaptychus Trauth, 1927 (cf. Měchová et al., 2010, fig. 7D). Our specimens are only fragmentarily preserved, and the upper part of the lateral margin is mostly missing. However, the ribbing and dimensions of Lamellaptychus sp. (López-Caballero, 2009, pl. 10, fig. D4) of our specimens are characteristic for Lamellaptychus murocostatus Trauth, 1929, that is described in detail by Trauth (1938). According to Trauth (1938, p. 142), the $\mathrm{W} / \mathrm{L}$ ratio is approximately 0.63 (0.56 in Renz, 1978, p. 502); ribs are slightly higher than wide and accompanying furrows are slightly less wide. The width of these furrows is gradually decreasing towards the inner margin and the values of $\mathrm{pW}$ and $\mathrm{S}$ are almost equal $(\mathrm{pW} / \mathrm{S}=0.90 \mathrm{in}$ Renz, 1978, p. 502).

Lamellaptychus beyrichi (Oppel, 1865) is similar to L. murocostatus, but, according to Trauth (1938, p. 142), the latter differs in the presence of wall-like, upturned ribs leaning towards the lateral margin.

Occurrence. Lamellaptychus murocostatus Trauth, 1929 was previously documented from the Oxfordian of the western North Atlantic (Site 105, Leg XI, Deep Sea Drilling Project; Renz, 1978) and from the Tithonian of Austria (Trauth, 1929,
1938). In Mexico, the taxon was reported from the Kimmeridgian upper Idoceras Beds of Puerto Piñones (López-Caballero, 2009, "layer 8E" in fig. 3) and from the upper Kimmeridgian Procraspedites-Taramelliceras interval (see Villaseñor et al., 2012) of Sierra de Palotes, State of Durango (Villaseñor and González-Arreola, 1988).

Lamellaptychus murocostatus is here described from the Kimmeridgian or Tithonian of the La Caja Formation at La Mesita, State of San Luis Potosí, and the Kimmeridgian or Tithonian of Rincón del Agua Dulce and Pablillo, both in the State of Nuevo León.

\section{Discussion}

The Upper Jurassic aptychus faunal assemblage of northeastern Mexico is low in diversity when compared to time-equivalent aptychus occurrences of the Tethyan Realm. The species reported here from the Kimmeridgian to Tithonian are of limited stratigraphical distribution in Mexico. While Lamellaptychus is restricted to the upper lower Kimmeridgian-lower upper Tithonian, records of the genus Laevaptychus reach from the uppermost Kimmeridgian to uppermost Tithonian.

All identified Kimmeridgian-Tithonian aptychi were previously known from the Tethyan Realm. Laevaptychus (Latuslaevaptychus) latus meyrati Trauth, 1931, Laevaptychus (Autharislaevaptychus) favrei Trauth, 1931 and Lamellaptychus lamellosus (Parkinson, 1811) are here described for Mexico for the first time, which thus extends their palaeogeographic distribution from the Tethys into the western hemisphere. Migration may have been via the Hispanic Corridor, a pathway that likely existed since the Early Jurassic, connecting the Tethys with the Gulf of Mexico and the Pacific Ocean (e.g., Damborenea, 2000; Aberhan, 2001). Less well-known, however, and quite questionable to date is the hypothesis that this seaway also connected with the northwestern Gulf of Mexico (e.g. NE Mexico) (e.g., Verma and Westermann, 1973; Adatte et al., 1994, 1996). Positive evidence of faunal 
exchange is given since the earliest Cretaceous by abundant shared occurrences of ammonite, bivalve, belemnite and calpionellid taxa in both northeastern Mexico and Europe (e.g., Trejo, 1960, 1976, 1980; Stinnesbeck et al., 1993; Adatte et al., 1994, 1996; Zell et al., 2013, 2014), but earlier, i.e. latest Jurassic faunal migration pathways, are less well understood. It appears that this pathway was only intermittently open for short intervals of the Kimmeridgian and Tithonian stages, as indicated by short intervals with Boreal belemnites (Zell et al., 2013), the bivalve Anopaea (Zell et al., 2015) and cold-water-indicative ammonites (Zell and Stinnesbeck, 2015), and now by the occurrence of Tethyan aptychi.

On the other hand, no endemic aptychi were identified during our survey. This result is unexpected considering the rare access to the northwestern Gulf of Mexico, of Late Jurassic European, or Tethyan, faunal elements, including the high portion of endemic ammonite taxa (e.g., Verma and Westermann, 1973; Villaseñor et al., 2000, 2012). Aptychi do not appear to follow that pattern, which cannot presently be explained.

\section{Conclusions}

Here we describe a new and relatively complete aptychi assigned to Laevaptychus and Lamellaptychus. These individuals were collected in northeastern Mexico in the Kimmeridgian-Tithonian succession of the La Caja Formation. Lamellaptychus murocostatus Trauth, 1929 and Laevaptychus (Hoplisuslaevaptychus) mexicanus (Castillo and Aguilera, 1895) were previously reported from Mexico, while Laevaptychus (Latuslaevaptychus) latus meyrati Trauth, 1931, Laevaptychus (Autharislaevaptychus) favrei Trauth, 1931 and Lamellaptychus lamellosus (Parkinson, 1811) are here described from Mexico for the first time. All identified taxa are well known from the Tethyan Realm, where they occur in time-equivalent strata, with exception of the Oxfordian Laevaptychus (Autharislaevaptychus) favrei Trauth, 1931, which extends into the Tithonian of Mexico. The presence of Tethyan aptychi in Mexico provides additional evidence for faunal exchange across the Hispanic Corridor. The absence of endemic aptychi is quite unexpected, as only a few associated Kimmeridgian and Tithonian ammonite taxa are of Tethyan origin.

\section{Acknowledgements}

The authors acknowledge Josep Anton Moreno Bedmar and Zdeněk Vašíček for their helpful comments and corrections to the manuscript. Financial support to this research was provided by the Deutsche Forschungsgemeinschaft (DFG STI 128-17 and 128/30; to W.S.).

\section{References}

Aberhan, M., 2001, Bivalve palaeobiogeography and the Hispanic Corridor: time of opening and effectiveness of a proto-Atlantic seaway: Palaeogeography, Palaeoclimatology, Palaeoecology, 165, 375-394.

Adatte, T., Stinnesbeck, W., Hubberten, H., Remane, J., 1994, The JurassicCretaceous boundary in Northeastern Mexico. Confrontation and correlations by microfacies, clay minerals mineralogy, calpionellids and ammonites: Geobios, Mémoire Spécial, 17, 37-56.

Adatte, T., Stinnesbeck, W., Remane, J., Hubberten, H., 1996, Paleoceanographic changes at the Jurassic-Cretaceous boundary and the Western Tethys, northeastern Mexico: Cretaceous Research, 17, 671-689.

Beydoun, Z.R., 1966, Eastern Aden Protectorate and part of Dhufar, in Geukens, F. (ed.), Geology of the Arabian Peninsula, Yemen: Geological Survey Professional Paper, 560B, H1-H49.

Bronn, H.G., 1850-51, Oolithengebirge, MesoLethaea: Lethaea geognostica, IV. Teil, dritte Periode, Stuttgart, 11(3), 1-374. 
Buchy, M.-C., Frey, E., Stinnesbeck, W., LópezOliva, J.G., 2003, First occurrence of a gigantic pliosaurid plesiosaur in the late Jurassic (Kimmeridgian) of Mexico: Bulletin de la Société Géologique de France, 174(3), 271-278.

Buchy, M.-C., Frey, E., Stinnesbeck, W., LópezOliva, J.G., 2005, An annotated catalogue of the Upper Jurassic (Kimmeridgian and Tithonian) marine reptiles in the collections of the Universidad Autónoma de Nuevo León, Facultad de Ciencias de la Tierra, Linares, Mexico: Oryctos, 6, 13-30.

Burckhardt, C., 1906, La fauna Jurassique de Mazapil avec un appendice sur les fossiles de Crétacique inférieur: Boletín del Instituto Geológico de México, 23, 1-217.

Burckhardt, C., 1912, Faunes jurassiques et crétaciques de San Pedro del Gallo, État de Durango, México: Boletín del Instituto de Geología, 29, 1-260.

Burckhardt, C., 1930, Etude synthétique sur le Mésozoïque Mexicain: Mémoires de la Société paléontologique de Siusse, 49/50, $1-280$.

Calzada, S., 1985, Braquiopodos del Hauteriviense de Fortuna (Prov. Murcia, España): Bolletino della Societa Paleontologica Italiana, 23, $75-90$.

Cantú-Chapa, A., 1963, Étude biostratigraphique des Ammonites du centre et de l'est du Mexique (Jurassique supérieur et Crétacé): Mémoires de la Société géologiques de France 99, nouvelle série, mémoire, 42, $1-102$.

Cantú-Chapa, A., 2006, New Upper Tithonian (Jurassic) ammonites from Chinameca Formation in southern Veracruz, eastern Mexico: Journal of Paleontology, 80(2), 294 308

Castillo, A. Del, Aguilera, J.G., 1895, Fauna Fósil de la Sierra de Catorce, San Luis Potosí: Boletín de la Comisión Geológica de México, $1,1-55$.
Damborenea, S.E., 2000, Hispanic corridor: Its evolution and the biogeography of bivalve molluscs, in Hall, R.L., Smith, P.L. (eds.), Advances in Jurassic Research: GeoResearch Forum, 6, 369-380.

Deslongchamps, E., 1835, Mémoire sur les coquilles fossils du genre Münsteria: Mémoires de la Société linnéenne de Normandie, 5, 1-59, Paris.

Engel, T., 1908, Geognostischer Wegweiser durch Württemberg, 3. Auflage: Stuttgart, E. Schweizerbart sche Verlagsbuchhandlung E. Nägele, 645 p.

Erben, H.K., 1956, El Jurásico Medio y el Calloviano de México, XX Congreso Geológico Internacional; contribución al congreso del Instituto de Geología de la Universidad Nacional Autónoma de México, $140 \mathrm{p}$.

Farinacci, A., Mariotti, N., Matteucci, R., Nicosia, U., Pallini, G., 1976, Structural features of some Jurassic and Early Cretaceous Aptychi: Bolletino della Società Paleontologica Italiana, 15(2), 111-143.

Favre, E., 1876, Description des fossils du terrain Oxfordien des Alpes Fribourgeoises: Mémoires de la Société Paléontologique Suisse, 3, 1-75.

Fischer, J.C., 2003, Remarkable Invertebrates from the Lower Callovian of La Voultesur-Rhône (Ardèche, France): Annales de Paléontologie, 89, 223-252.

Fischer-Ooster, C. von, 1865, Beitrag zur paläontologischen Kenntniss der westlichen Schweizer-Alpen: Mitteilungen der Naturforschenden Gesellschaft in Bern, 580-602, 141-155.

Frey, E., Buchy, M.-G., Stinnesbeck, W., López Oliva, J.G., 2002, Geosaurus vignaudi n.sp. (Crocodyliformes: Thalattosuchia), first evidence of metriorhynchid crocodilians in the Late Jurassic (Tithonian) of central-east Mexico (Puebla): Canadian Journal of Earth Sciences, 39(10), 1467-1483. 
Gąsiorowski, S.M., 1959, Succession of Aptychi Faunas in the Western Tethys during the Bajocian-Barremian Time: Bulletin de l'Académie polonaise des Sciences, Série des Sciences de Géologie et Geographie, 7(9), 715-722.

Gąsiorowski, S.M., 1960, Remarques sur les Laevaptychi: Annales de la Société Géologique de Pologne, 30(1), 59-97.

Gąsiorowski, S.M., 1962, Aptychi from the Dogger, Malm and Neocomian in the Western Carpathians and their stratigraphical value: Studia Geologica Polonica, 10, 1-151.

Goldhammer, R.K., 1999, Mesozoic sequence stratigraphy and paleogeographic evolution of north east Mexico, in Bartolini, C., Wilson, J.L., Lawton, T.F. (eds.), Sedimentary and tectonic history of north central Mexico: Boulder, Colorado, Geological Society of America, Special Papers, 340, 1-31.

Goldhammer, R.K., Johnson, C.A., 2001, Middle Jurassic-Upper Cretaceous Paleogeographic Evolution and Sequence-stratigraphic Framework of the Northwest Gulf of Mexico Rim, in Bartolini, C., Buffler, R.T., Cantú-Chapa, A. (eds.), The Western Gulf of Mexico Basin: Tectonics, Sedimentary Basins, and Petroleum Systems: Tulsa, Oklahoma, The American Association of Petroleum Geologists Memoir, 75(3), 45-81.

Gümbel, G.W. von, 1861, Geognostische Beschreibung des bayerischen Alpengebirges und seines Vorlandes: Gotha, Verlag von Justus Perthes, 940 p.

Imlay, R.W., 1938, Studies on the Mexican Geosyncline: Bulletin of the Geological Society of America, 49, 1651-1694.

Imlay, R.W., 1939, Upper Jurassic Ammonites from Mexico: Bulletin of the Geological Society of America, 50, 1-78.

Imlay, R.W., 1941, Jurassic fossils from Arkansas, Louisiana, and Eastern Texas: Journal of Paleontology, 15(3), 256-277.

Instituto Nacional de Estadística, Geografía e Informática (INEGI), 2015, Topographic
Map of Mexico: Mexico, available at http:// mapserver.inegi.org.mx/CEM3_mapa/\#, accessed May, 2015.

Jenchen, U., 2007, Análisis sedimentológico, petrográfico y geoquímico de sedimentos clásticos en el Noreste de México: México, Universidad Autónoma de Nuevo León, Reporte técnico anual (inédito), Proyecto CT 1377-06: Programa de Apoyo a la Investigación Científica y Tecnología (PAICyT), 1-24.

Laur, P., 1871, Ammonites du Jurassique supérieur de Catorce, determines par le Prof. Bayle: De la Metallurgie de l’argent au Mexique, Annales des Mines, série 6, 1-38.

López-Caballero, I., 2009, Bioestratigrafía y tafonomía de la sección estratigráfica Puerto Piñones (Jurásico Superior) del área de Saltillo, Coahuila, México: Mexico, Universidad Nacional Autónoma de México, Master thesis (unpublished).

Loriol, P. de, Royer, E., Tombeck, H., 1872, Monographie paléontologique et géologique des étages supérieurs de la formation Jurassique de la Haute-Marne: Mémoires de la Société Linnéenne de Normandie, vol. 16, $1-484$.

Měchová, L., Vašíček, Z., Houša, V., 2010, Early Cretaceous ribbed aptychi - a proposal for a new systematic classification: Bulletin of Geosciences, Czech Geological Survey, Prague, 85(2), 219-274.

Meyer, H.v., 1829, Das Genus Aptychus: Nova Acta Physico-Medica Academiae Cesareae Leopoldino-Carolinae Naturae Curiosum, 15(2), 125-170.

Meyer, H.v., 1831, Das Genus Aptychus: Neues Jahrbuch für Mineralogie, Geognosie, Geologie und Petrefakten-Kunde, Heidelberg, 1 1, Jahrgang, 1-391.

Michalzik, D., 1988, Trias bis tiefste Unter-Kreide der nordöstlichen Sierra Madre Oriental, Mexiko: Germany, University of Darmstadt, Ph.D. thesis, 247 p. (unpublished). 
Mora, A. De la, Olóriz, F., González-Arreola, C., 2000, 'Autochthonous' bivalve assemblages and palaeoecologic interpretation in the Upper Jurassic-Lowermost Cretaceous La Caja Formation from the Cañón de San Matías (Zacatecas, México): Earth and Planetary Sciences, 331, 741-747.

Olóriz, F., 1992, North-central and eastern Mexico, in Westermann, G.E.G. (ed.), The Jurassic of the Circum-Pacific, Part III: Regional geology and stratigraphy, MesoAmerica: Cambridge, Cambridge University Press, 100-107.

Olóriz, F., Villaseñor, A.B., González-Arreola, C., 1998, Re-evaluation of Procraspedites Spath, 1930 (Ammonitina) from the Upper Kimmeridgian of Mexico: Bulletin de la Société Géologique de France, 2, 243-254.

Olóriz, F., Villaseñor, A.B., González-Arreola, G., Westermann, G.E.G., 1999, Ammonite biostratigraphy and correlations in the Latest Jurassic-Earliest Cretaceous La Caja Formation of North-Central Mexico (Sierra de Catorce, San Luis Potosí), in Olóriz, F., Rodríguez-Tovar, F.J. (eds.), Advancing Research on Living and Fossil Cephalopods: London, Plenum Press, 463-492.

Olóriz, F., Villaseñor, A.B., González-Arreola, C., 2003, Major lithostratigraphic units in landoutcrops of north-central Mexico and the subsurface along the northern rim of Gulf of Mexico Basin (Upper Jurassic-lowermost Cretaceous): a proposal for correlation of tectono-eustatic sequences: Journal of South American Earth Sciences, 16, 119-142.

Ooster, W.A., 1857, Catalogue des cephalopods fossiles des Alpes suisses avec la description et les figures des espèces remarquables: Zurich, Imprimerie de Zurcher et Furrer, Part I \& II, $32 \mathrm{p}$.

Oppel, A., 1863, Über jurassische Cephalopoden: Stuttgart, Palaeontologische Mittheilungen aus dem Museum des königlich bayrischen Staates, 1. Band, Text und Atlas, 127 p.
Oppel, A., 1865, Die tithonische Etage: Zeitschrift der Deutschen Geologischen Gesellschaft, $17,1-547$.

Parkinson, J., 1811, The Fossil Starfish, Echini, Shells, Insects, Amphibia, Mammalia \& c: London, The Organic Remains of a Former World, Sherwood, Neely, and Jones, 3, 479 p.

Peters, K., 1854, Die Aptychen derösterreichischen Neocomien- und oberen Juraschichten: Wien, Jahrbuch der kaiserlich königlich geologischen Reichsanstalt, Band V, 1-439.

Pictet, F.-J., 1854, Traité de Paléontologie, ou Histoire Naturelle des Animaux Fossiles: Paris, J.-B. Baillière, II édition, tome 11, 551 p.

Pozzi, R., 1965, Nuova fauna ad Aptici del Malm dell isola di Rodi (Grecia): Rivista italiana di Paleontologia e Stratigrafia, Milano, 71(3), 855-880.

Quenstedt, F.A., 1846-49, Petrefactenkunde Deutschlands, Cephalopoden: Tübingen, Ludwig Friedrich Fues, 1. Band, 72 p.

Quenstedt, F.A., 1858, Der Jura: Tübingen, Laupp, Text und Atlas, $842 \mathrm{p}$.

Quenstedt, F.A., 1887-88, Die Ammoniten des schwäbischen Jura, Der weiße Jura (Malm): Stuttgart, E. Schweizerbeart`sche Verlagshandlung (E. Koch), Text und Atlas, 3. Band, $344 \mathrm{p}$.

Răileanu, G., Năstăseanu, A., 1960, Contributions concerning the Upper Cretaceous ammonites fauna from Svinița: Studii şi Cercetări Geologice, 5(1), 7-38 (in Romania).

Renz, O., 1972, Aptychi (Ammonoidea) from the Upper Jurassic and Lower Cretaceous of the western north Atlantic (Site 105, Leg 11, Deep Sea Drilling Project): Deep Sea Drilling Project, 11, 607-629.

Renz, O., 1978, Aptychi (Ammonoidea) from the Late Jurassic and Early Cretaceous of the eastern Atlantic, DSDP site 367: Deep Sea Drilling Project , 16, 499-513.

Schindewolf, O.H., 1958, Über Aptychen (Ammonoidea): Palaeontographica, A 111, $1-46$. 
Spath, L.F., 1925, The Collection of fossils and rocks from Somaliland made by Messrs. B.N.K. Wyllie and W.R. Smellie, Part 7: Ammonites and Aptychi: Monographs of the Geological Department of the Hunterian Museum, 1, 111-164.

Spath, L.F., 1931, Revision of the Jurassic Cephalopod Fauna of Kachh (Cutch): Paleontologica Indica, NS, 9(4), 279-550.

Stinnesbeck, W., Adatte, T., Remane, J., 1993, Mazatepec (Estado de Puebla, México) Reevaluación de su valor como estratotipo del Límite Jurásico-Cretácico: Revista Española de Micropaleontología, 25(2), 6379.

Stinnesbeck, W., Frey, E., 2014, Paleogeography and Paleoenvironment of Mexico during the Mesozoic, in Rivera-Sylva, H.R.-S., Carpenter, K., Frey, E. (eds.), Dinosaurs and other Reptiles from the Mesozoic of Mexico: Bloomington, Indiana University Press, 1329.

Thurmann, J., Etallon, A., (1861-1864), Lethea Bruntrutana ou etudes paleontologiques et stratigraphiques sur le Jura bernois et en particulier les environs de Porrentruy: Switzerland, Mémoire de la Société des Sciences Naturelles, 20, 357-412.

Toula, F., 1907, Die Acanthicus-Schichten im Randgebirge der Wiener Bucht bei Gießhübl (Mödling WNW): Wien, Geologische Reichsanstalt, Band 16, Heft 2, 299-305.

Trauth, F., 1927-1931, Aptychenstudien I-VII: Wien, Annalen des Naturhistorischen Museums, 41, 171-259 (1927); 42, 171-259 (1928); 44, 329-411 (1930); 45, 17-136 (1931); 47, 127-145 (1936).

Trauth, F., 1929, Geologie der Klippenregion von Ober-St. Veit und des Lainzer Tiergartens: Wien, Mitteilungen der Geologischen Gesellschaft, 21, 76-80.

Trauth, F., 1938, Die Lamellaptychen des Oberjura und der Unterkreide: Palaeontographica Abt. A, 88, 115-229.
Trauth, F., 1948, Die fazielle Ausbildung und Gliederung des Oberjura in den nördlichen Ostalpen: Verhandlungen der Geologischen Bundesanstalt, 10-12, 10-218.

Trejo, H.M., 1960, La familia Nannoconidae y su alcance estratigráfico en América: Boletín de la Asociación Mexicana de Geólogos Petroleros, 12(9, 10), 259-314.

Trejo, H.M., 1976, Tintinidos mesozóicos de México (Taxonomia y datos paleobiológicos): Boletín de la Asociación Mexicana de Geólogos Petróleros, 27, 329-449.

Trejo, H.M., 1980, Distribución estratigrafica de los Tintínidos mesozoicos mexicanos: Revista del Instituto Mexicano del Petróleo, 12(4), 4-13.

Turculeț, I., 2000, Aptihii din România: Bucureşti, Ed. Academiei Română, 178 p.

Turculet,, I., Grigore, D., 2006, New Upper Jurassic aptychi from the Svintia area (south Carpathians, Romania): Oltenia, Muzeul Olteniei Craiova, Studii și comunicări, Stiințele Naturii, 22, 28-39.

Valduga, A., 1954, Ammoniti ed aptici neogiurassici dell Ogaden e della Somalia sud-occidentale: Palaeontographia Itatica, $48,1-40$.

Vašíček, Z., Motchurova-Dekova, N., Ilcheva, A., Metodiev, L., 2012, Taxonomy of Late Jurassic-Early Cretaceous aptychi from Bulgaria: Neues Jahrbuch für Geologie und Paläontologie, Abhandlungen, 265/3, 249274.

Velasco Segura, J.A., 2005, Análisis Litológico y estratigráfico de la Formación La Caja en la "Sierra El Jabalí", Saltillo, Coahuila, México: Mexico, Universidad Autónoma de Nuevo León, Master thesis, (unpublished).

Verma, H.M., Westermann, G.E.G., 1973, The Tithonian (Jurassic) ammonite fauna and stratigraphy of Sierra de Catorce, San Luis Potosí, Mexico: Bulletins of American Paleontology, 63(277), 107-320. 
Villaseñor, A.B., González-Arreola, G., 1988, Fauna de ammonites y presencia de Lamellaptychus murocostatus Trauth del Jurásico superior de la Sierra de Palotes, Durango: Revista del Instituto de Geología, 7(1), $71-$ 77.

Villaseñor, A.B., Olóriz, F., González-Arreola, C., 2000, Recent advances in Upper Jurassic (Kimmeridgian - Tithonian) ammonite biostratigraphy of north-central Mexico based on recently collected ammonite assemblages: GeoResearch Forum, 6, 249262.

Villaseñor, A.B., Olóriz, F., López-Palomino, I., López-Caballero, I., 2012, Updated ammonite biostratigraphy from Upper Jurassic deposits in Mexico: Revue de Paléobiologie, Genève, vol. spec., 11, 249267.

Voltz, P.L., 1837, Zweiter Vortrag über das Genus Aptychus, in Leonhard, K.C. von, Bronn, H.G. (eds.), Neues Jahrbuch für Mineralogie, Geognosie, Geologie und PetrefaktenKunde: Stuttgart, E. Schweizerbart'sche Verlagshandlung, 432-438.

Zell, P., Beckmann, S., Stinnesbeck, W., 2013, Late Jurassic-earliest Cretaceous belemnites (Cephalopoda: Coleoidea) from northeastern Mexico and their palaeobiogeographic implications: Neues Jahrbuch für Geologie und Paläontologie, Abhandlungen, 270/3, 325-341.
Zell, P., Beckmann, S., Stinnesbeck, W., 2014, Age and depositional conditions of the marine vertebrate concentration Lagerstätte at Gomez Farías, southern Coahuila, Mexico: Journal of South American Earth Sciences, 56, 91-109.

Zell, P., Stinnesbeck, W., 2015, Kimmeridgian (Late Jurassic) cold-water idoceratids (Ammonoidea) from southern Coahuila, northeastern Mexico, associated with Boreal bivalves and belemnites: Revista Mexicana de Ciencias Geológicas, 32(1), 11-20.

Zell, P., Crame, J.A., Stinnesbeck, W., Beckmann, S., 2015, The bivalve Anopaea (Inoceramidae) from the Upper Jurassiclowermost Cretaceous of Mexico: Journal of South American Earth Sciences, 60, 92-103. Zigno, A. de, 1870, Annotazioni paleontologiche: Venetia, Memorie del Reale Instituto Veneto di Scienze, Lettre ed Arti, 15, 1-27. 